\title{
Development and Survival of Neurons in Dissociated Fetal Mesencephalic Serum-Free Cell Cultures: II. Modulatory Effects of Gangliosides
}

\author{
A. Leon, R. Dal Toso, D. Presti, D. Benvegnù, L. Facci, G. Kirschner, G. Tettamanti, ${ }^{1}$ and G. Toffano \\ Fidia Neurobiological Research Laboratories, Abano Terme, and 'Institute of Biological Chemistry, University of Milano, \\ Milano, Italy
}

\begin{abstract}
This paper analyzes the effects of exogenously supplied GM1 on the development, i.e., specific neurotransmitter uptake capability and survival, of the dopaminergic neurons present in fetal mouse-dissociated mesencephalic cells. Exogenous GM1, but not asialo-GM1, sialic acid, or the oligosaccharide chain of GM1, enhances in a time- and concentration-dependent manner the specific ${ }^{3} \mathrm{H}$-dopamine uptake (increase of the apparent $V_{\max }$ and decrease of the apparent $K_{\mathrm{m}}$ value) and the long-term survival of the dopaminergic neurons. The GM1 effects on the behavior of the dopaminergic neurons require the presence of cell-derived neuronotrophic influences present within the culture system and are associated with an increase in the response of the cells to the trophic influences. GM1 effects are not limited to dopaminergic neurons, and depend on the stable association of the ganglioside molecule with the cells. It is suggested that GM1 is not a trophic agent per se, but rather potentiates neuronotrophic activities and/or exerts independent influences to which neurons respond only if appropriately supported.
\end{abstract}

It is becoming increasingly evident that not only the development but also the repair of the nervous system is controlled by extracellular signals whose physiological effects most probably depend on their interaction with molecules expressed on the cell surface (Frazier and Glaser, 1979). Although detailed studies of glycolipid expression and function on the neuronal cell surface are still in their infancy, gangliosides appear to play a prominent role in regulating both neuronal development and repair. During development, brain ganglioside patterns undergo marked changes, both quantitatively and qualitatively (Willinger and Schachner, 1980; Koulakoff et al., 1983). In regenerating adult axons, cell synthesis and axonal transport of gangliosides increase (Sbaschnig-Agler et al., 1984). While antibodies to gangliosides inhibit nerve regeneration (Sparrow et al., 1984), ganglioside administration in vivo has been reported to facilitate nerve regeneration and functional recovery of the PNS following

\footnotetext{
Received May 5, 1986; revised July 7, 1987; accepted July 7, 1987.

We are extremely grateful to Professor G. F. Azzone (Institute of General Pathology, University of Padova, Padova, Italy) and to Dr. S. Skaper for helptul discussions both during the course of the work and in preparing the manuscript. In addition, we wish to express our gratitude to Miss E. Olivi, Miss A. Bedeschi, and Mrs. R. Pressato for expert secretarial assistance.

Correspondence should be addressed to Dr. Alberta Leon, Fidia Research Laboratories, Via Ponte della Fabbrica 3/A, 35031 Abano Terme, Italy.

Copyright $\odot 1988$ Society for Neuroscience 0270-6474/88/030746-08\$02.00/0
}

injury (Ceccarelli et al., 1976; Gorio et al., 1980, 1983; Sparrow and Graftstein, 1982; Robb and Keynes, 1984). Furthermore, the administration of gangliosides, in particular monosialoganglioside GM1 (nomenclature according to Svennerholm, 1963), has been reported to ameliorate the outcome following injury to the CNS (Wojcik et al., 1982; Agnati et al., 1983; Karpiak, 1983; Toffano et al., 1983, 1984; Carmignoto et al., 1984; Fass and Ramirez, 1984; Kojima et al., 1984; Jonsson et al., 1984; Oderfeld-Nowak et al., 1984; Sabel et al., 1984, 1985; Casamenti et al., 1985; Fujito et al., 1985; Commissiong and Toffano, 1986; Cuello et al., 1986; Fusco et al., 1986; Gradkowska et al., 1986; Hadjiconstantinou and Neff, 1986; Hadjiconstantinou et al., 1986; Sofroniew et al., 1986).

In an attempt to understand the role of gangliosides in regulating neuronal development and repair, the effects of exogenous GM1 addition to neuronal cells in culture have been evaluated in a variety of studies. Neurons, both primary and clonal, respond to the ganglioside with pronounced morphological changes characteristic of cell differentiation (Leon et al. 1982, 1984; Byrne ct al., 1983; Fcrrari ct al., 1983; Rybak ct al., 1983; Facci et al., 1984; Katoh-Semba et al., 1984; Doherty et al., 1985; Skaper and Varon, 1985; Skaper et al., 1985; Matta et al., 1986). In this paper we report the effects of GM1 addition on the behavior of dopaminergic neurons in dissociated embryonic mouse mesencephalic cells cultured in a serum-free, hormone-supplemented medium. In these cultures, more than $98 \%$ of the mesencephalic cells can be classified as neurons on the basis of immunocytochemical criteria (Dal Toso et al., 1988). Survival and expression of specific high-affinity neurotransmitter uptake of the dopaminergic neurons appear to be dependent on adequate levels of trophic influences, either produced in culture or exogenously supplied. GM1 ganglioside enhances both dopaminergic cell survival and maturation only in the presence of adequate trophic influences. This effect is correlated with stable cell association of the gangliosides, and suggests that exogenously supplemented gangliosides may affect neuronal behaviors in vitro, and perhaps also in vivo, by facilitating membrane-mediated cellular responses to endogenously occurring neuronotrophic signals.

\section{Materials and Methods}

Materials. Commercial chemicals were of analytical grade, or of the highest purity available. Solvents were distilled before use. The water routincly cmployed was freshly taken from a Milli-Q reagent water system (Millipore, Molsheim, France). BSA, bovine pancreatic insulin, human transferrin, putrescine, $L-3,5,3^{\prime}$-triiodothyronine $\left(T_{3}\right)$, progesterone, sodium selenite, L-2,4-diaminobutyric acid (DABA), amino- 
Table 1. Effects of GM1 on BZT-sensitive ${ }^{3} \mathrm{H}-\mathrm{DA}$ uptake by mesencephalic cell cultures

GM1 concentrations (M)

\begin{tabular}{lcccc} 
& 0 & $10^{-8}$ & $5 \times 10^{-8}$ & $10^{-7}$ \\
\cline { 2 - 5 } $\begin{array}{l}\text { DNA content }(\mu \mathrm{g} / \text { dish }) \\
\text { BZT-sensitive }{ }^{3} \mathrm{H}-\mathrm{DA} \text { uptake } \\
\quad\end{array}$ & $7.5 \pm 0.9$ & $7.6 \pm 0.9$ & $7.1 \pm 1.2$ & $7.2 \pm 0.7$ \\
$\quad(\mathrm{fmol} / \mu \mathrm{g}$ DNA per $15 \mathrm{~min})$ & $11.03 \pm 0.8$ & $20.25 \pm 0.4^{b}$ & $23.3 \pm 2.2^{b}$ & $29.5 \pm 3.5^{b}$ \\
$\begin{array}{l}\text { Kinetic parameter } \\
\quad K_{\mathrm{m}}\left(10^{-7} \mathrm{M}\right)\end{array}$ & 1.045 & - & - & 0.354 \\
$\quad V_{\max }(\mathrm{fmol} / \mu \mathrm{g}$ DNA per $15 \mathrm{~min})$ & 55 & - & - & 174
\end{tabular}

Dissociated cells were suspended in control and GM1-containing (serum-free) media, seeded at $1 \times 10^{6}$ per plate $/ 2 \mathrm{ml}$, and cultured for $4 \mathrm{~d}$. See Materials and Methods for assay of DNA content and BZT-sensitive ${ }^{3} \mathrm{H}-\mathrm{DA}$ uptake. Values are mean \pm SEM of triplicate analyses. For kinetic analysis ${ }^{3} \mathrm{H}-\mathrm{DA}$ uptake was measured using $30,50,100,200$, and $400 \mathrm{nM}$ DA and apparent $K_{\mathrm{m}}$ and $V_{\max }$ values were calculated from Hofstee plots (triplicate points for each concentration). ${ }^{a}$ Assessed using $5 \times 10^{-8} \mathrm{M}^{3} \mathrm{H}-\mathrm{DA}$.

${ }^{b} p<0.01$; Student's $t$ test (vs control value).

oxyacetic acid, pargyline chlorhydrate, ascorbic acid, and calf thymus type I DNA were purchased from Sigma (St. Louis, MO); ${ }^{3} \mathrm{H}$-dopamine (DA; sp act, $22-33 \mathrm{Ci} / \mathrm{mmol}$ ) and GABA (sp act, $225 \mathrm{mCi} / \mathrm{mmol}$ ) from New England Nuclear (NEN, Dreieich, FRG), 3,5-diaminobenzoic acid from Serva (Heidelberg, FRG); benztropine mesylate (BZT) from Merck, Sharp \& Dohme (Quebec, Canada); Eagle's basal medium from Gibco (New York); Ham's F12 nutrient mixture from Flow Laboratories (McLean, VA); bovine skin collagen (Vitrogen) from Collagen Corp. (Palo Alto, CA); the preblended liquid-scintillation solution, Instagel II, from Packard (Downers Grove, II.). Mouse monoclonal antibody to rat neurofilament RT97 (anti-NF) (Anderton et al., 1982) and mouse glial fibrillary acidic protein (GFAP) antiserum were a gift of Dr. F. S. Walsh (Institute of Neurology, The National Hospital, London, UK).

Cell culture preparation and composition. Dissociated mesencephalic and striatal cell cultures were prepared as previously described (Prochiantz et al., 1979; Di Porzio et al., 1980). Briefly, rostral mesencephalic tegmentum and corpus striatum from brains of 13-and 15-d-old mouse embryos, respectively, were dissected under the microscope in sterile conditions and dissociated mechanically. The cells were centrifuged at $45 \times g$ for $4 \mathrm{~min}$ and resuspended in a serum-free medium consisting of equal volumes of Eagle's basal medium and Ham's F12, supplemented with components as reported in the preceding paper by Dal Toso et al. (1988). Two milliliters of cell suspension containing the desired amounts of cells were added to collagen-coated 35 -mm-diameter tissue culture dishes (Falcon). The cultures were incubated at $37^{\circ} \mathrm{C}$ in a watersaturated $\left(95 \%\right.$ air; $5 \% \mathrm{CO}_{2}$ ) atmosphere. As previously reported (Dal Toso et al., 1988), more than $98 \%$ of the cells plated at $0.5-2 \times 10^{6} \%$ dish and cultured for 4 or $8 \mathrm{~d}$ were identified as neurons by their immunoreactivity to anti-NF, and less than $1 \%$ of them stained positively with GFAP antiserum.

${ }^{3} \mathrm{H}$-dopamine and GABA uptake. Prior to uptake studies, culture medium was removed, cells washed extensively with PBS containing glucose (6 gm/liter), $\mathrm{Ca}^{2+}(1 \mathrm{mM})$, and $\mathrm{Mg}^{2+}(1 \mathrm{mM})$. Assay of ${ }^{3} \mathrm{H}$-dopamine (DA) uptake was conducted as previously described (Prochiantz et al., 1981; Dal Toso et al., 1988). With the exception of kinetic studies, $5 \times 10^{-8} \mathrm{M}{ }^{3} \mathrm{H}-\mathrm{DA}$ was routinely employed. GABA was assayed as described by Prochiantz et al. (1981). In brief, uptake of GABA was routinely measured by addition of $0.1 \mu \mathrm{M}{ }^{14} \mathrm{C}-\mathrm{GABA}$ for $15 \mathrm{~min}$ at $37^{\circ} \mathrm{C}$. Amino-oxyacetic acid $(10 \mu \mathrm{M})$ was used to prevent GABA catabolism. GABA uptake inhibitors were added when necessary. Washing and extraction procedures were as described for ${ }^{3} \mathrm{H}-\mathrm{DA}$ uptake studies. GABA identification was performed by thin-layer chromatography (I asher, 1974). More than $90 \%$ of the radioactivity was associated with a spot comigrating with authentic GABA.

Histochemical visualization. Histochemical visualization of catecholaminergic neurons in culture was performed following noradrenergic uptake using the glyoxylic acid-induced fluorescence (GIF) technique, as previously described (Dal Toso et al., 1988). The GIF+ neurons were visualized with a Zeiss III photomicroscope equipped with catecholamine epifluorescence and phase-contrast optics. Using prefixed coordinates, $\mathrm{GIF}^{+}$neurons were counted over at least $3 \%$ of the total surface area.

GMI characterization and preparation of GMI-containing media. GM1 ganglioside, extracted from calf brain according to Tettamanti et al.
(1973), was purified and chemically characterized as described by Sonnino et al. (1978). Chromatographic analysis indicated that the purity of GM1 was over $99 \%$. No amino acid peaks were detected by automated amino acid analysis after acid hydrolysis of $100 \mathrm{mg}$ GM1. Desired amounts of purified GM1 were dissolved in chloroform-methanol ( $1: 1$ by volume), dried again and redissolved in an appropriate volume of incubation medium in order to reach the final ganglioside concentration (from $10^{-8}$ to $10^{-7} \mathrm{M}$ ). The solution was maintained at $37^{\circ} \mathrm{C}$ for at least $1 \mathrm{hr}$, with intermittent swirling. The recovery of GMl by this procedure, as measured using ${ }^{3} \mathrm{H}-\mathrm{GM} 1$ labeled on the terminal galactose moiety (Facci et al., 1984), exceeded 90\%. The control medium was treated in the same way except for the omission of GM1. Solvents were distilled before use.

When needed, appropriate amounts of GM3, asialo-GM1, and GDlb were substituted for GM1. These were a gift from Professor G. Tettamanti (Institute of Biological Chemistry, University of Milano, Milano, Italy) and their purity exceeded $99 \%$.

Determination of cell-associated GMI radioactivity. Association of GM1 to mesencephalic cells in culture was essentially conducted as described by Facci et al. (1984). ${ }^{3} \mathrm{H}-\mathrm{GM} 1$ labeled on the terminal galactose moiety was used. The specific radioactivity was $1.5 \mathrm{Ci} / \mathrm{mmol}$ and its specific radiochemical purity was over $99 \%$. In brief, collagencoated coverslips without and with mesencephalic cells were incubated at $37^{\circ} \mathrm{C}$ for different times, with ${ }^{3} \mathrm{H}-\mathrm{GM} 1\left(10^{-8}-10^{-7} \mathrm{M}\right)$ in serum-free medium. After incubation, coverslips were washed twice with PBS, once with the culture medium supplemented with $10 \%$ fetal calf serum $(30$ min at $37^{\circ} \mathrm{C}$ ), and 3 more times with PBS. The radioactivity of each coverslip was extracted twice with $5 \mathrm{ml}$ aliquots of tetrahydrofuran (THF), as described by Tettamanti et al. (1973). The THF extracts were brought to dryness under a nitrogen stream and resuspended with $1 \mathrm{ml}$ distilled water prior to the addition of $10 \mathrm{ml}$ of emulsifier (Instagel II). Samples were then counted by liquid scintillation with a Packard Tricarb (model $460 \mathrm{C}$ ) counter. Residual radioactivity due to GM1 association to collagen was subtracted. TLC identification of radioactivity was conducted as reported previously (Facci et al., 1984). Dried coverslips were then processed for DNA assay (Erwin et al., 1981). THF treatment did neither interfere with the DNA assay nor modify the DNA content of the coverslips.

\section{Results}

\section{GM1 effects on specific ${ }^{3} \mathrm{H}-\mathrm{DA}$ uptake}

The high-affinity ${ }^{3} \mathrm{H}-\mathrm{DA}$ uptake of the fetal mouse-dissociated mesencephalic neurons, specifically inhibited by BZT, was used as an index to determine the effect of exogenously supplied GM1 on dopaminergic cells (Dal Toso et al., 1988). Addition of GM1 (from $10^{-8}$ to $10^{-7} \mathrm{M}$ ) to dissociated mesencephalic cells at plating time did not modify the neuronal ( $\mathrm{RT}^{-2} 7^{+}$) to astroglial (GFAP+) cell ratio nor the total DNA content per dish when assessed at day 4 (Table 1). GM1 produced a concentrationdependent increase of the BZT-sensitive ${ }^{3} \mathrm{H}$-DA uptake without changes in the BZT-insensitive levels. Kinetic analysis indicated 
Figure 1. BZT-sensitive DA uptake (A) and DABA-sensitive GABA uptake $(B)$ as a function of cell density. Effect of GM1. Dissociated mesencephalic cells were seeded at various cell densities in serum-free culture medium without $(O)$ or with (O) $10^{-7}$ M GM1. Uptakes were assayed at day 4 in vitro, as reported in Materials and Methods. Each valuc is the mean \pm SEM of triplicate analyses. See text for further details.
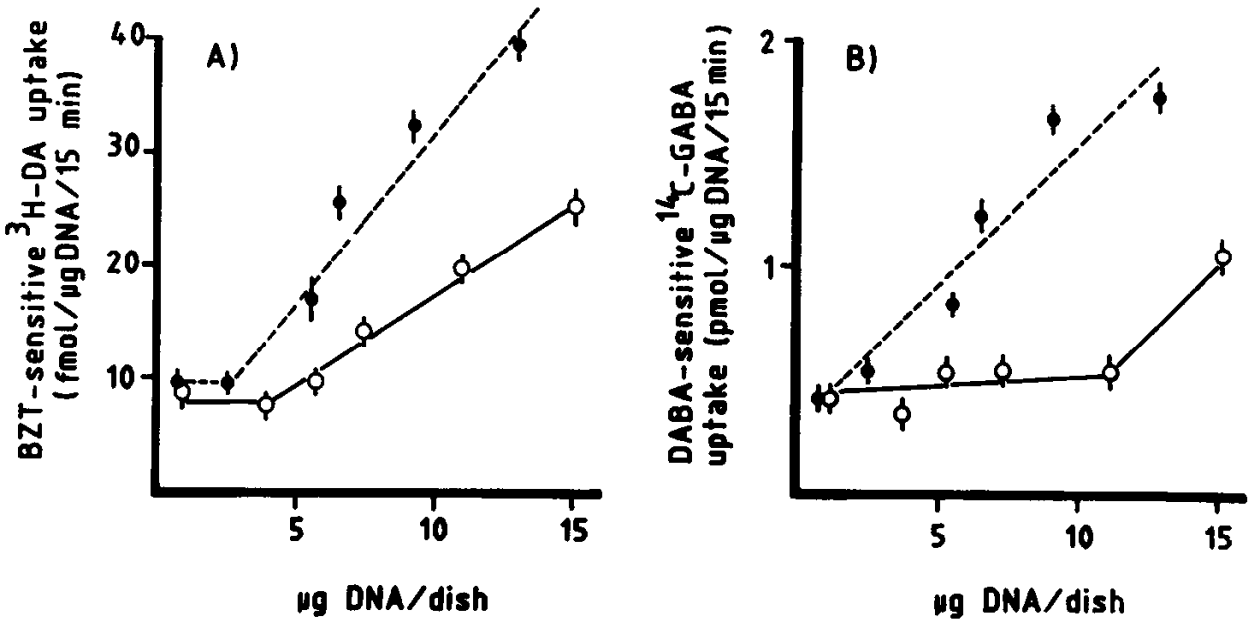

that the GM1 effect was associated with a 3-fold increase of the apparent $V_{\max }$ and 3-fold reduction of the apparent $K_{\mathrm{m}}$ value. The GM1-induced increase was evident after $2 \mathrm{~d}$ (control $=$ $25.15 \pm 5.84 \mathrm{fmol} /$ plate; GM1, $10^{-7} \mathrm{M},-41.17 \pm 1.34 \mathrm{fmol} /$ plate), and persisted up to at least $8 \mathrm{~d}$ (Table 2). Transient exposure of cell cultures to GM1 for up to $2 \mathrm{hr}$ before or during the ${ }^{3} \mathrm{H}-\mathrm{DA}$ uptake assay was totally ineffective.

\section{Correlation with cell density}

Since DA uptake capacity of the mesencephalic dopaminergic neurons is dependent on the cell density (Dal Toso et al., 1988), we investigated the effects of GM1 at increasing plating cell densities (Fig. $1 A$ ). As previously reported, in the absence of GM1 the BZT-sensitive DA uptake was constant up to an apparent threshold of approximately $3 \mu \mathrm{g} \mathrm{DNA}$ at day 4 (about $0.5 \times 10^{6}$ plated cells) and subsequently increased linearly with increasing cell density (or porportional to the square of the cell density on a per-plate basis). In GM1-treated cultures, the same pattern was observed, but the slope of the cell density-induced increase was approximately 1.5-2-fold greater. Although slopes of the amplitude of the cell-derived influences differed among different cell batches, the relative effect of GM1 was similar.
Interestingly, the cell density effect on specific DA uptake was only kinetically correlated with an increase in the apparent $V_{\max }$ $\left(V_{\max }=72.8\right.$ or $230.0 \mathrm{fmol} / \mu \mathrm{g}$ DNA in $15 \mathrm{~min}$ when using $1 \times$ $10^{6}$ or $2 \times 10^{6}$ cells plated/dish, respectively). No significant modifications in the apparent $K_{\mathrm{m}}$ values were observed $\left(K_{\mathrm{m}}=\right.$ 0.127 or $0.110 \mu \mathrm{M}$, respectively, using $1 \times 10^{6}$ or $2 \times 10^{6}$ plated cells). However the addition of GM1, as reported above, both increased the apparent $V_{\max }$ values and decreased the apparent $K_{\mathrm{m}}$ values.

\section{Correlation with number and viability of dopaminergic neurons}

Table 2 shows data relative to the time course of the number of dopaminergic, i.e., $\mathrm{GIF}^{+}$cells seeded at a density of 1 or $2 \times$ $10^{6}$ cells. In GM1-free cultures, as previously reported (Dal Toso et al., 1988), doubling of the $1 \times 10^{6}$ plating cell density did not significantly alter the proportion of dopaminergic cells surviving at $4 \mathrm{~d}$ (about $0.15 \%$ of the total seed), but reduced by half the dopaminergic cell losses between 4 and $8 \mathrm{~d}$ (from $75 \%$ to about $35 \%$ ). The higher plating cell density further caused an approximately 2 -fold increase of the $B Z \mathrm{C}$-sensitive DA uptake per dopaminergic neuron, the latter uptake also increasing with

Table 2. Correlation between BZT-sensitive DA uptake and number of dopaminergic neurons in mesencephalic cell cultures: effects of GM1

\begin{tabular}{lllcr} 
Parameters & Cells plated & Days & Control & GM1 $\left(\mathbf{1 0}^{7} \mathbf{M}\right)$ \\
\hline DA cells/plate & $1 \times 10^{6}$ & 4 & $1451 \pm 152$ & $1632 \pm 186$ \\
& $1 \times 10^{6}$ & 8 & $350 \pm 157$ & $368 \pm 148$ \\
& $2 \times 10^{6}$ & 4 & $3340 \pm 234$ & $3592 \pm 301$ \\
DA uptake (dpm)/plate & $2 \times 10^{6}$ & 8 & $2159 \pm 171$ & $3030 \pm 250^{a}$ \\
& $1 \times 10^{6}$ & 4 & $2852 \pm 210$ & $4613 \pm 511^{a}$ \\
& $1 \times 10^{6}$ & 8 & $1396 \pm 116$ & $2681 \pm 215^{a}$ \\
DA uptake (dpm)/DA cell & $2 \times 10^{6}$ & 4 & $14,940 \pm 1035$ & $21,740 \pm 1957^{a}$ \\
& $2 \times 10^{6}$ & 8 & $13,192 \pm 1123$ & $19,546 \pm 1467^{a}$ \\
& $1 \times 10^{6}$ & 4 & 1.96 & 2.83 \\
& $1 \times 10^{6}$ & 8 & 3.99 & 7.28 \\
& $2 \times 10^{6}$ & 4 & 4.47 & 6.06 \\
& $2 \times 10^{6}$ & 8 & 6.11 & 6.45
\end{tabular}

Dissociated mesencephalic cells ( 1 and $2 \times 10^{6}$ plated cells) were grown for 4 or $8 \mathrm{~d}$ in vitro in the presence of serumfree culture media with or without $10^{-7} \mathrm{M}$ GMl. At appropriate times, the BZT-sensitive DA uptake and number of $\mathrm{GIF}^{+}$neurons were assessed in sister cultures, as reported in Materials and Methods. Values are mean \pm SEM of triplicate analyses for each assay.

${ }^{a} p<0.05 ;$ Student's $t$ test (vs control value). 
Table 3. Specificity of the GM1 molecule

\begin{tabular}{lll} 
Addition $\left(10^{-7} \mathbf{M}\right)$ & $\begin{array}{l}\text { BZT-sensitive } \\
{ }^{3} \mathrm{H}-\mathrm{DA} \text { uptake }\end{array}$ & $\begin{array}{l}\text { DABA-sensi- } \\
\text { tive }{ }^{14} \mathrm{C}-\mathrm{GABA} \\
\text { uptake }^{a}(\%)\end{array}$ \\
\hline- & $100 \pm 15$ & $100 \pm 28$ \\
$\mathrm{GM1}$ & $154 \pm 9$ & $557 \pm 20$ \\
$\mathrm{GM} 3$ & $142 \pm 5$ & $579 \pm 47$ \\
$\mathrm{GD}_{1 \mathrm{~b}}$ & $159 \pm 10$ & $645 \pm 30$ \\
Asialo-GM1 & $93 \pm 15$ & $118 \pm 31$ \\
Sialic acid & $88 \pm 14$ & $96 \pm 34$ \\
Oligosaccharide $^{b}$ & $98 \pm 17$ & $102 \pm 41$
\end{tabular}

Mesencephalic cells $\left(1 \times 10^{6} /\right.$ plate $)$ were grown for $4 \mathrm{~d}$ in serum-free medium with and without the above components. All components were added to a concentration of $10^{-7} \mathrm{M}$. Uptake assays were conducted as reported in Materials and Methods. Values are referred to specific uptake per plate with respect to control values $\left(87.1 \mathrm{fmol}{ }^{3} \mathrm{H}-\mathrm{DA} / \mathrm{plate}\right.$ and $\left.0.68 \mathrm{pmol}^{14} \mathrm{C}-\mathrm{GABA} / \mathrm{plate}\right)$ and are the mean \pm SEM of 2 independent experiments conducted in triplicate with each assay. See Materials and Methods for preparation and purity of compounds.

${ }^{a}$ Evaluated at day $4\left(1 \times 10^{6}\right.$ cells/plate $)$ in vitro.

${ }^{b}$ Oligosaccharide component is referred to the oligosaccharide chain containing sialic acid of the GM1 molecule and was obtained from Professor G. Tettamanti (Institute of Biological Chemistry, University of Milano, Milano, Italy). For ganglioside nomenclature, see Svennerholm (1963).

time in culture. GM1 treatment did not significantly affect the number of dopaminergic cells at all plating densities or culture times, except that in the higher-density cultures it reduced the $8 \mathrm{~d}$ cell loss to only about $15 \%$ of the $4 \mathrm{~d}$ number. At the lower plating density, GM1 also increased by $50 \%$ the DA uptake per dopaminergic cell at both 4 and $8 \mathrm{~d}$, and at the higher plating density, only at $4 \mathrm{~d}$, perhaps because the uptake capacity was already maximal in the higher-density $8 \mathrm{~d}$ cultures. The protective effect of GM1 on the late dopaminergic cell losses was not restricted only to dopaminergic neurons, since the DNA content per plate also decreased less in the presence than in the absence of GM1 (15\% decrease instead of $52 \%)$.

\section{Neuronal specificity}

The high-affinity ${ }^{14} \mathrm{C}$-GABA uptake, abolished by $1 \mathrm{~mm}$ DABA (an inhibitor of neuronal GABA uptake), is considered specific to GABAergic neurons and is used as a parameter of GABAergic activity (Prochiantz et al., 1981). In the mesencephalic cultures, the DABA-sensitive ${ }^{14} \mathrm{C}$-GABA uptake was linear up to at least 30 min of incubation al $37^{\circ} \mathrm{C}$ and reached its maximum value after $4 \mathrm{~d}$ in culture. Addition of $1 \mathrm{~mm} \beta$-alanine, a selective inhibitor of glial GABA uptake, did not produce any further inhibition. This is in accord with the presence of very few glial elements in our culture system.

As already reported, in cultures of increasing cell density the DABA-sensitive ${ }^{14} \mathrm{C}$-GABA uptake, when referred to per $10^{6}$ platcd cells, increased, if at all, only at relatively high cell densities (Dal Toso et al., 1988). As shown in Figure $1 B$, GMl $\left(10^{-7}\right.$ M) markedly enhanced the DABA-sensitive ${ }^{14} \mathrm{C}$-GABA uptake in 4-d-old cultures at all cell densities. Moreover, at $1 \times 10^{6}$ cells/plate, the GM1-induced increase of specific GABA uptake was concentration-dependent ( 97 and $156 \%$ increase with $10^{-8}$ and $10^{-7} \mathrm{M}$ GM1, respectively). The kinetic analysis, conducted in the presence of $10^{-7} \mathrm{M} G M 1$, indicated that, also in this case, there was an increase in the apparent $V_{\max }$ (control $=2.47 \pm$ $0.06 ; \mathrm{GM} 1=3.22 \pm 0.03 \mathrm{pmol} / \mu \mathrm{g}$ DNA per $15 \mathrm{~min})$ and a reduction in the apparent $K_{\mathrm{m}}$ value (from $1.67 \pm 0.10$ to $0.78 \pm$ $0.09 \mathrm{M})$. In addition, the GM1 effect on specific GABA uptake was not restricted to mesencephalic cells. GM1 stimulated the

\begin{tabular}{|c|c|}
\hline & $\begin{array}{l}\text { Serum-stable-associated } \\
{ }^{3} \mathrm{H}-\mathrm{GM} 1(\mathrm{pmol} / \mu \mathrm{g} \text { DNA })\end{array}$ \\
\hline \multicolumn{2}{|c|}{ Ligand concentration (M) } \\
\hline $1 \times 10^{-8}$ & $0.201 \pm 0.019$ \\
\hline $5 \times 10^{-8}$ & $1.373 \pm 0.080$ \\
\hline $1 \times 10^{-1}$ & $2.960 \pm 0.130$ \\
\hline \multicolumn{2}{|c|}{ Time of exposure (hr) } \\
\hline 0.5 & $0.941 \pm 0.087$ \\
\hline 1.0 & $1.193 \pm 0.012$ \\
\hline 2.0 & $1.373 \pm 0.153$ \\
\hline 24.0 & $4.597 \pm 0.341$ \\
\hline
\end{tabular}

Mesencephalic cells $\left(1 \times 10^{6 / d i s h}\right)$ were cultured for $1 \mathrm{~d}$, then exposed for $2 \mathrm{hr}$ to serum-free medium containing ${ }^{3} \mathrm{H}-\mathrm{Ga}-\mathrm{GMl}$ at the concentrations indicated, or exposed to $5 \times 10^{-8} \mathrm{M}^{3} \mathrm{H}-\mathrm{Ga}$-GM1 for the indicated times. Ligand exposures were at $37^{\circ} \mathrm{C}$ in a water-saturated $95 \%$ air, $5 \% \mathrm{CO}_{2}$ incubator. At all times, the extracted radioactivity comigrated with authentic GMI on TLC plates. Values are means ( \pm SEM) from triplicate samples in each of 2 independent experiments.

DABA-sensitive ${ }^{14} \mathrm{C}-\mathrm{GABA}$ uptake in 4-d-old dissociated fetal striatal cell cultures in serum-free conditions (from a control value of $1.12 \pm 0.16$ to $1.80 \pm 0.09 \mathrm{pmol} / \mu \mathrm{g}$ DNA per $15 \mathrm{~min}$, with $10^{-7} \mathrm{M}$ GM1 added to $1 \times 10^{6}$ plated cells). There too, no GM1 effect was observed on striatal cell viability at 4 d, as evaluated on the basis of phase-contrast microscopy and DNA content per dish.

\section{Molecular specificity}

Other gangliosides, possessing a chemical structure similar to GM1, were tested for their effects on specific DA and GABA uptake by cultured mesencephalic cells. Table 3 shows that similar increases were produced by monosialogangliosides such as GM3, which lacks the 2 terminal sugar residues, and disialogangliosides, such as GDlb. In contrast, asialo-GM1, which lacks the $N$-acetylneuraminic acid, was totally ineffective. Free sialic acid or the oligosaccharide chain of GMl also had no activity.

\section{Relationship between association of GM1 to cells and uptake parameters}

As shown in Table 4, stable association of GM1 to mesencephalic cells increased with increasing concentrations and time of incubation, as already reported for $\mathrm{N}_{2} \mathrm{~A}$ neuroblastoma cells (Facci et al., 1984). Exposure of mesencephalic cells to $10^{-7} \mathrm{M}$ GM1 only for the first $24 \mathrm{hr}$ in culture affected the specific uptake of both DA and GABA (Table 5). The effect was, however, smaller than that in cultures in which GM1 was present throughout the $4 \mathrm{~d}$ without changes of the culture medium. The GM1 effects after $24 \mathrm{hr}$ of incubation werc accompanicd only by a decrease in the apparent $K_{\mathrm{m}}$ values: from 9.1 to $4.05 \times 10^{-8} \mathrm{M}$ for the DA uptake and from 1.8 to $0.87 \times 10^{-6} \mathrm{M}$ for the GABA uptake. No significant changes were observed in the apparent $V_{\max }$ values. Apparently, the affinity constants of the uptake systems are more readily sensitive to GM1 addition, while modifications in the apparent $V_{\max }$ value seem to necessitate longer exposure to GM1. It should be mentioned that the change of the incubation medium to interrupt the effect of GM1 may result in modification not only of the extent of GM1 association to the cells, compared to the $4 \mathrm{~d}$ incubation, but also in cell density effects. Whether the former or the latter factor is of greater importance is at present unclear. 
Table 5. Effect of the addition, at various times, of GM1 on specific ${ }^{3} \mathrm{H}$-DA uptake in mesencephalic cells in culture

\begin{tabular}{ccl} 
Treatment time & $\begin{array}{l}\text { BZT-sensitive } \\
{ }^{3} \text { H-DA uptake } \\
\text { (fmol/plate for 15 min) }\end{array}$ & $\begin{array}{l}\text { DABA-sensitive } \\
{ }^{14} \mathrm{C}-\text { GABA uptake } \\
\text { (pmol/plate for } \\
15 \mathrm{~min})\end{array}$ \\
\hline $0-24 \mathrm{hr}$ & & \\
Control & $8.56 \pm 1.04$ & $0.11 \pm 0.01$ \\
GM 1 & $14.98 \pm 0.70$ & $0.30 \pm 0.07$ \\
$0-96 \mathrm{hr}$ & & \\
Control & $15.22 \pm 3.55$ & $0.15 \pm 0.03$ \\
GM 1 & $41.41 \pm 1.70$ & $0.58 \pm 0.12$
\end{tabular}

Mesencephalic cells $\left(1 \times 10^{5}\right)$ were cultured in serum-free medium with or without $10^{-7} \mathrm{M}$ GM1 either for only $1 \mathrm{~d}$ or for 4 consecutive $\mathrm{d}$. In the former case, medium was removed from control and GM1-treated cultures and substituted with fresh culture medium containing no GMl. All cultures were incubated for another $3 \mathrm{~d}$ and uptakes were assessed at $d 4$. Values are the mean \pm SEM of triplicate analyses.

\section{Discussion}

The data reported here show that exogenously supplied GM1, but not asialo-GM1, sialic acid, or the oligosaccharide chain of GM1, enhances DA uptake and long-term survival of dopaminergic neurons in fetal mouse-dissociated mesencephalic cells cultured in serum-free conditions. GM1 also increases specific ${ }^{14} \mathrm{C}$-GABA uptake in mesencephalic and striatal cultures and long-term survival of the bulk population of mesencephalic neurons (as judged by DNA content of the culture). This multiplicity of GM1 effects seems to reflect a capacity to affect development of neurotransmitter uptake activity and survival of various CNS neuronal cell types in vitro without any regional spccificity. This is in accord with previous reports concerning facilitation by gangliosides of neuronal differentiation (i.e., neurite outgrowth, synaptogenesis, and/or tubulin mRNA induction) of a variety of clonal and primary neuronal cells in culture (Obata et al., 1977; Morgan and Seifert, 1979; Dimpfel et al., 1981; Hauw et al., 1981; Roisen et al., 1981; Leon et al., 1982; Byrne et al., 1983; Ferrari et al., 1983; Rybak et al., 1983; Spoerri, 1983; Tsuji et al., 1983; Dreyfus et al., 1984; Katoh-Semba et al., 1984; Doherty et al., 1985; Hefti et al., 1985b; Skaper and Varon, 1985; Skaper et al., 1985; Matta et al., 1986).

\section{Relationship between GM1 effects and trophic influences in vitro}

The GM1 effects on the dopaminergic neurons in the mesencephalic cell cultures appear to require the presence of cellderived influences supporting their development, i.e., in terms of specific neurotransmitter uptake capability, and survival. GM1 is ineffective in low-density cultures and effective in higherdensity cultures. Thus, GM1 seems to be unable to substitute for the cell-derived influences, but rather to potentiate the action of the latter or, in any case, to exert effects to which neurons respond only if appropriately supported. A similar relationship has been observed between GM1 and NGF in pheochromocytoma cells (PC12) and in fetal chicken dorsal root (DRG) and sympathetic ganglionic cells in culture (Ferrari et al., 1983; Katoh-Semba et al., 1984; Leon et al., 1984; Doherty et al., 1985; Skaper and Varon, 1985; Skaper et al., 1985; Matta et al., 1986). In addition, GM1 has been shown to have a permissive effect on the response of fetal chicken ciliary ganglia neurons to the chicken eye ciliary neuronotrophic factor (CNTF) (Skaper et al., 1985). Together these data suggest that the GM1 molecule does not possess per se trophic activity, but is capable of affecting the efficacy of different trophic agents acting on specific neuronal types. Nonetheless, on comparison in the mesencephalic cell cultures between dopaminergic and GABAergic neurons, it appears that the GMI effects and their relationship to trophic support may vary among neuronal cell types in vitro. In particular, the amplitude of the GMl-induced potentiation of the cellderived influences on DA uptake in the mesencephalic cells was constant (approximately 1.7-fold) at all cell densities beyond the threshold. Furthermore, the effects on DA uptake of GM1 plus fetal mouse-dissociated striatal cells, known to enhance specific DA uptake per dopaminergic cell (Prochiantz et al., 1979; Di Porzio et al., 1980), were additive (data not reported). This indicates that GM 1 and both the mesencephalic and striatal cell-derived influences affect dopaminergic neurons via different mechanisms. In contrast, the amplitude of the GM1-induced potentiation of GABA uptake increased with increasing cell density (at least up to $1.5 \times 10^{6}$ plated cells), suggesting that GM1 may have increased the sensitivity of the GABAergic cells to subthreshold concentrations of the cell-derived influences. Hence, the mechanisms underlying the GMI potentiation of trophic activity on neuronal cells in vitro may not be unique, and may vary with the cell type and its developmental stage. In addition, it may depend on the type of trophic signal (e.g., survival versus cell-cell interactions) operative at a particular developmental stage of the neurons. Support for this latter view derives from evidence indicating that cell surface gangliosides play a modulatory role not only in signal-mediated cell growth and differentiation but also in cell adhesion and cell-cell recognition (Hakomori, 1981; Ando, 1983; Bremer et al., 1984, 1986; Blackburn et al., 1986; Thompson et al., 1986).

It is noteworthy that ganglioside addition to embryonic ratdissociated septal cells in culture has recently been reported to enhance choline acetyltransferase (ChAT) activity but not NGFmediated increase of ChAT activity (Hefti et al., 1985b). Furthermore, NGF does not increase survival or fiber outgrowth of the cultured fetal septal cholinergic neurons (Hefti et al., 1985a). The functional significance of the NGF-stimulated ChAT activity in these cultures and its relationship to its well-known neuronotrophic effect in PNS neurons requires further clarification. In this study, NGF addition to the mesencephalic cell cultures was ineffective both on uptake parameters and cell survival.

\section{Types of GMI effects in vitro}

Two neuronal behaviors are affected by the cell density and GM1. One of these is neuronal survival. Endogenous agents provided by $1 \times 10^{6} \mathrm{cells} / \mathrm{dish}$ are adequate to support neuronal survival, but only for $4 \mathrm{~d}$ (during which time GMl addition yields no numcrical improvement). Longer survival (e.g., $8 \mathrm{~d}$ ) requires exogenous supplementation from additional CNS cells or CNS tissue extracts (Dal Toso et al., 1988). The present study shows that GMI enhances the effects of cell supplementation. In addition, similar results were obtained in experiments conducted using GM 1 and a bovine striatal extract (data not shown). Hence, GM1 enhances the benefits of both supplements. The other neuronal behavior affected by GM1 and cell density is DA (or GABA) uptake. In principle, an increase of neurotransmitter uptake at nonsaturating substrate concentrations may be due to decrease of apparent $K_{\mathrm{m}}$, presumably a reflection of an increased efficiency of the transport mechanism. This is not the case for the increase of $V_{\max }$. In fact, the increase of $V_{\max }$ reflects 
not only the number of specific cells but also their membrane surface (e.g., neurite extension) and/or the number of uptake sites per unit surface. While the apparent $K_{\mathrm{m}}$ is decreased by GM1 but not by an increase of the cell density, $V_{\max }$ is increased by increase of cell density as well as by GM1. The question arises as to the relationship between this differential behavior and the molecular mechanisms underlying the cell density and the GM1 effects.

One may visualize the occurrence of GM1 effects on multiplemembrane constituents (see below). The first, reflected by an increase in number of uptake sites, is apparently related to the potentiation by GM1 of the neuronotrophic, cell-derived influences, and may be due to ganglioside potentiation of transmembrane signaling of the trophic influences. This is probably related to ganglioside stimulation of the trophic-dependent neurite outgrowth. In fact, although neurite outgrowth has not been evaluated in this study, GM1 has been reported to facilitate neurite outgrowth in cells both with and without an absolute neuronotrophic requirement for survival and/or neurite extension (Byrne et al., 1983; Ferrari et al., 1983; Facci et al., 1984; KatohSemba et al., 1984; Leon et al., 1984; Skaper and Varon, 1985; Skaper et al., 1985; Matta et al., 1986). Interestingly, in chicken DRG cells in vitro, gangliosides potentiate NGF-induced neurofilament expression and maintenance (Doherty et al., 1985) while antibodies to GM1 block in a dose-dependent manner the NGF-induced neurite outgrowth (Schwartz and Spirman, 1982). In SB2IB2 cells, there occurs during ganglioside-induced differentiation a significant increase in the expression of mRNA for tubulin (Rybak et al., 1983). Besides the above, gangliosides are known to modify a number of membrane functions, presumably depending on the nature of the membrane constituent with which they interact. In fact, gangliosides are known to cause changes of membrane properties including enzyme activity (Partington and Daly, 1979; Davis and Daly, 1980; Leon et al., 1981; Goldenring et al., 1985), receptor binding (Hollmann and Seifert, 1986; Montecucco, 1986), receptor-mediated signal transduction (Bremer et al., 1984, 1986; Berry-Kravis and Dawson, 1985; Bar-Sinai et al., 1986), and ion permeability (Vyskocil et al., 1985). Likely, the GM1-induced increased efficiency of the uptake system is a reflection of GM1 interactions with the neurotransmitter carrier system.

\section{Mechanisms of GM1 effects: relationship to cell association of GMI}

The question now arises with regard to the mechanisms underlying the multiple ganglioside effects. Although the answer is largely obscure, the results reported here have shown that the portion of stably associated GM1 is probably involved in the effects observed on the dopaminergic and GABAergic neurons. Incubation of various cells in the presence of gangliosides, including GM1, results in a time- and temperature-dependent cell accumulation of the added glycolipid, even in the absence of endocytosis (Moss et al., 1976; Radsak et al., 1982; Schwarzmann et al., 1983; Facci et al., 1984). Although some of the gangliosides can be released by treatment of the cells with serum or trypsin, it appears that a residual portion (trypsin-insensitive) is tightly associated with the outer leaflet of the plasma membrane. At the concentration used in this study, the cell-associated GM1 is mainly trypsin-resistant (Facci et al., 1984). Spin-labeled ganglioside analogs indicate that the trypsin-insensitive form of cell membrane-associated glycolipid displays characteristic anisotropic ESR spectra (Schwarzmann et al., 1983), which closely resemble those of spin-labeled analogs at low dilution in artificial vesicles. The stably associated gangliosides are both functionally and metabolically active (Moss et al., 1976; Fishman et al., 1983; Sonderfeld et al., 1985). Likely, the surface packing of gangliosides and/or the ganglioside interactions with membrane proteins and phospholipids in defined microdomains of the bilayer play a strategic role in the supramolecular organization and functional properties of the membrane components (Spiegel et al., 1985; Tettamanti et al., 1985). Another possibility is that the stably cell-associated exogenous gangliosides undergo internalization and recycling via direct glycosylation, resulting in de novo synthesis of more complex gangliosides (Ghidoni et al., 1983; Sonderfeld et al., 1985). These cause modification of the cell surface ganglioside pattern, which, in turn, may affect the membrane properties.

\section{Relationship between ganglioside effects in vitro and in vivo}

The question has been raised as to whether the findings obtained in vitro are relevant as models for the ganglioside-mediated effects in vivo. Hefti et al. (1985b) have concluded that the ganglioside effects on maintenance and/or recovery of function following CNS injury in vivo are related to the ganglioside-induced attenuation of astrocyte proliferation, rather than to their effects on neuronal cells in vitro. The argument has been that the concentrations at which gangliosides act on neuronal cells in vitro $(0.05-0.75 \mathrm{mg} / \mathrm{ml}$ of medium) are higher than those obtained during in vivo administration $(10-50 \mathrm{mg} / \mathrm{kg}$ of body weight). While, in the above-mentioned study, high concentrations of gangliosides in vitro were employed to evidence their effects on astrocyte morphology and proliferation, others have shown that similar concentrations of individual gangliosides may be toxic for astroglial cells in culture (Skaper et al., 1986). In the present study, the effect of gangliosides is obtained at concentrations of $15-150 \mathrm{ng} / \mathrm{ml}$, compatible with the ganglioside concentrations obtainable in the brain after its systemic administration in vivo (Ghidoni et al., 1986). We therefore favor the view that the GM1 effects in vivo on neuronal repair processes are related to its capability to enhance neuronal cell responsiveness to endogenously occurring neuronotrophic factors.

Neuronotrophic factors are known to be present in the adult brain and to increase following brain injury. Although their physiological relevance still remains to be established, recent experiments conducted with NGF (Hefti, 1986; Williams et al., 1986) suggest that they presumably play a primary role in the maintenance of cell survival following CNS injury. Interestingly, GM1 treatment has been reported to facilitate neuronal cell survival not only of dopaminergic and noradrenergic neurons, but also of cholinergic neurons known to be NGF-responsive (Agnati et al., 1983; Toffano et al., 1984; Commissiong and Toffano, 1986; Cuello et al., 1986; Sofronicw ct al., 1986).

\section{References}

Agnati, L. F., K. Fuxe, L. Calzá, F. Benfenati, L. Cavicchioli, G. Toffano, and M. Goldstein (1983) Gangliosides increase the survival of lesioned nigral dopamine neurons and favour the recovery of dopaminergic synaptic function in the striatum of rats by collateral sprouting. Acta Physiol. Scand. 119: 347-363.

Anderton, B. H., D. Brcinburg, M. J. Downes, P. J. Green, B. E. Tomlinson, J. Ulrich, J. N. Wood, and J. Kahn (1982) Monoclonal antibodies show that neurofibrillary tangles and neurofilaments share antigenic determinants. Nature 298: 84-86.

Ando, S. (1983) Gangliosides in the nervous system. Neurochem. Int. 5: $507-537$

Bar-Sinai, A., Y. Aldouby, M. Chorev, and A. Levitzki (1986) As- 
sociation of turkey erythrocyte $\beta$-adrenoceptors with a specific lipid component. EMBO J. 5: 1175-1180.

Berry-Kravis, E., and G. Dawson (1985) Possible role of gangliosides in regulating an adenylate cyclase-linked 5-hydroxytryptamine (5HT) receptor. J. Neurochem. 45: 1739-1747.

Blackburn, C. C., P. Swank-Hill, and R. L. Schnaar (1986) Gangliosides support neural retina cell adhesion. J. Biol. Chem. 261: 28732881.

Bremer, E. G., S. Hakomori, D. Bowen-Pope, E. Raines, and R. Ross (1984) Ganglioside-mediated modulation of cell growth, growth factor binding and receptor phosphorylation. J. Biol. Chem. 259: 68186825.

Bremer, E. G., J. Schlessinger, and S. Hakomori (1986) Gangliosidemediated modulation of cell growth. Specific effects of GM3 on tyrosine phosphorylation of the epidermal growth factor receptor. J. Biol. Chem. 261: 2434-2440.

Byrne, M. C., R. W. Ledeen, F. J. Roisen, G. Yorke, and J. R. Sclafani (1983) Ganglioside-induced neuritogenesis: Verification that gangliosides are the active agents, and comparison of molecular species. J. Neurochem. 41: 1214-1222.

Carmignoto, G., R. Canella, and S. Bisti (1984) Can functional reorganization of area 17 following monocular deprivation be modified by GM1 internal ester treatment? J. Neurosci. Res. 12: 477-483.

Casamenti, F., L. Bracco, L. Bartolini, and G. Pepeu (1985) Effects of ganglioside treatment in rats with a lesion of the cholinergic forebrain nuclei. Brain Res. 338: 45-52.

Ceccarelli, B., F. Aporti, and M. Finesso (1976) Effects of brain gangliosides on functional recovery in experimental regeneration and reinnervation. In Ganglioside Function, G. Porcellati, B. Ceccarelli, and G. Tettamanti, eds., pp. 275-293, Plenum, New York.

Commissiong, J. W., and G. Toffano (1986) The effect of GM1 ganglioside on coerulospinal, noradrenergic, adult neurons and on fetal monoaminergic neurons transplanted into the transected spinal cord of the adult rat. Brain Res. 380: 205-215.

Cuello, A. C., P. H. Stephen, P. C. Tagari, M. V. Sofroniew, and R. C. A. Pearson (1986) Retrograde changes in the nucleus basalis of the rat, caused by cortical damage, are prevented by exogenous ganglioside GM1. Brain Res. 376: 373-377.

Dal Toso, R., O. Giorgi, C. Soranzo, G. Kirschner, G. Ferrari, M. Favaron, D. Benvegnù, S. Vicini, G. Toffano, G. F. Azzone, and A. Leon (1988) Development and survival of neurons in dissociated fetal mesencephalic serum-free cultures: I. Effects of cell density and of an adult mammalian striatal-derived neuronotrophic factor (SDNF). J. Neurosci. 8: 733-745.

Davis, C. W., and J. W. Daly (1980) Activation of rat cerebral cortical $3^{\prime}, 5^{\prime}$-cyclic nucleotide phosphodiesterase activity by gangliosides. Mol. Pharmacol. 17: 206-211.

Dimpfel, W., W. Möller, and U. Mengs (1981) Ganglioside-induced neurite formation in cultured neuroblastoma cells. In Gangliosides in Neurological and Neuromuscular Function, Development and Repair, M. M. Rapport and A. Gorio, eds., pp. 119-134, Raven, New York.

Di Porzio, U., M. C. Daguet, J. Glowinski, and A. Prochiantz (1980) Effect of striatal cells on in vitro maturation of mesencephalic dopaminergic neurons grown in serum-free conditions. Nature 288:370373.

Doherty, P., J. G. Dickson, T. P. Flanigan, and F. S. Walsh (1985) Ganglioside GM1 does not initiate, but enhances neurite regeneration of nerve growth factor-dependent sensory neurones. J. Neurochem. 44: 1259-1265.

Dreyfus, H., B. Ferret, S. Harth, A. Gorio, L. Freysz, and R. Massarelli (1984) Effect of exogenous gangliosides on the morphology and biochemistry of cultured neurons. In Gangliosides Structure, Function and Biochemical Potential, R. W. Ledeen, R. K. Yu, M. M. Rapport, and K. Suzuki, cds., pp. 513-524, Plenum, Ncw York.

Erwin, B. G., C. M. Stoscheck, and J. R. Florini (1981) A rapid fluorometric method for the estimation of DNA in cultured cells. Anal. Biochem. 110: 291-294.

Facci, L., A. Leon, G. Toffano, S. Sonnino, R. Ghidoni, and G. Tettamanti (1984) Promotion of neuritogenesis in mouse neuroblastoma cells by exogenous gangliosides. Relationship between the effect and the cell association of ganglioside GM1. J. Neurochem. 42: 299305.

Fass, B., and J. J. Ramirez (1984) Effects of ganglioside treatment on lesion-induced behavioral impairments and sprouting in the CNS. J. Neurosci. Res. 12: 445-458.

Ferrari, G., M. Fabris, and A. Gorio (1983) Gangliosides enhance neurite outgrowth in PC12 cells. Dev. Brain Res. 8: 215-222.

Fishman, P. H., R. M. Bradley, B. E. Hom, and J. Moss (1983) Uptake and metabolism of exogenous gangliosides by cultured cells: Effect of choleragen on the turnover of GM1. J. Lipid Res. 24: 1002-1011.

Frazier, W., and L. Glaser (1979) Surface components and cell recognition. Annu. Rev. Biochem. 48: 491-523.

Fujito, Y., S. Watanabe, H. Kobayashi, and N. Tsukahara (1985) Promotion of sprouting and synaptogenesis of cerebrofugal fibers by ganglioside application in the red nucleus. Neurosci. Res. 2: 407-411.

Fusco, M., M. Donà, F. Tessari, H. Hallman, G. Jonsson, and A. Gorio (1986) GM1 ganglioside counteracts selective neurotoxin-induced lesion of develoing serotonin neurons in rat spinal cord. J. Neurosci. Res. 15: 467-479.

Ghidoni, R., S. Sonnino, V. Chigorno, B. Venerando, and G. Tettamanti (1983) Occurrence of glycosylation and deglycosylation of exogenously administered ganglioside GM1 in mouse liver. Biochem. $J$. 213: 321-329.

Ghidoni, R., M. Trinchera, B. Venerando, A. Fiorilli, and G. Tettamanti (1986) Metabolism of exogenous GMI and related glycolipids in the rat. In Gangliosides and Neuronal Plasticity, G. Tettamanti, R. W. Ledeen, K. Sandhoff, Y. Nagai, and G. Toffano, eds., pp. 183-200, Liviana, Padova.

Goldenring, J. R., L. C. Otis, R. K. Yu, and R. J. De Lorenzo (1985) Calcium/ganglioside-dependent protein kinase activity in rat brain membrane. J. Neurochem. 44: 1229-1234.

Gorio, A., G. Carmignoto, L. Facci, and M. Finesso (1980) Motor nerve sprouting induced by ganglioside treatment. Possible implications for gangliosides on neuronal growth. Brain Res. 197: 236-241.

Gorio, A., P. Marini, and R. Zanoni (1983) Musclc rcinnervationIII. Motoneuron sprouting capacity, enhancement by exogenous gangliosides. Neuroscience 8: 417-429.

Gradkowska, M., M. Skup, L. Kiedrowski, S. Calzolari, and B. OderfeldNowak (1986) The effect of GM1 ganglioside on cholinergic and serotoninergic systems in the rat hippocampus following partial denervation is dependent on the degree of fiber degeneration. Brain Res. 375: 417-422.

Hadjiconstantinou, M., and N. H. Neff (1986) Treatment with GMl ganglioside increases rat spinal cord indole content. Brain Res. 366 : 343-345.

Hadjiconstantinou, M., Z. L. Rossetti, R. C. Paxton, and N. H. Neff (1986) Administration of GMl ganglioside restores the dopamine content in striatum after chronic treatment with MPTP. Neuropharmacology 25: 1075-1077.

Hakomori, S. (1981) Glycosphingolipids in cellular interaction, differentiation and oncogenesis. Annu. Rev. Biochem. 50:733-764.

Hauw, J. J., S. Fenelon, J.-M. Boutry, Y. Nagai, and R. Escourolle (1981) Effects of brain gangliosides on neurite growth in guinea pig spinal ganglia tissue cultures and on fibroblast cell cultures. In Gangliosides in Neurological and Neuromuscular Function, Development and Repair, M. M. Rapport and A. Gorio, eds., pp. 171-175, Raven, New York.

Hefti, F. (1986) Nerve growth factor promotes survival of septal cholinergic neurons after fimbrial transections. J. Neurosci. 6: 2155-2162.

Hefti, F., J. Hartikka, F. Eckenstein, H. Gnahn, R. Heumann, and M. Schwab (1985a) Nerve growth factor increases choline acetyltransferase but not survival or fiber outgrowth of cultured fetal septal cholinergic neurons. Neuroscience 14: 55-68.

Hefti, F., J. Hartikka, and W. Frick (1985b) Gangliosides alter morphology and growth of astrocytes and increase the activity of choline acetyltransferase in cultures of dissociated septal cells. J. Neurosci. 5: 2086-2094.

Hollmann, M., and W. Seifert (1986) Gangliosides modulate glutamate receptor binding in rat brain synaptic plasma membranes. Neurosci. Lett. 65: 133-138.

Jonsson, G., A. Gorio, H. Hallman, D. Janigro, H. Kojima, J. Luthman, and R. Zanoni (1984) Effect of GMI ganglioside on developing and mature serotonin and noradrenaline neurons lesioned by selective neurotoxins. J. Neurosci. Res. 12: 459-476.

Karpiak, S. E. (1983) Ganglioside treatment improves recovery of alternation behavior after unilateral entorhinal cortex lesion. Exp. Neurol. 81: 330-339.

Katoh-Semba, R., S. D. Skaper, and S. Varon (1984) Interaction of GM1 ganglioside with PC12 pheochromocytoma cells: Serum and NGF-dependent effects on neuritic growth (and proliferation). J. Neurosci. Res. 12: 299-310.

Kojima, H., A. Gorio, D. Janigro, and G. Jonsson (1984) GM1 gan- 
glioside enhances regrowth of noradrenaline nerve terminals in rat cerebral cortex lesioned by the neurotoxin 6-hydroxydopamine. Neuroscience 13: 1011-1022.

Koulakoff, A., B. Bizzini, and Y. Berwald-Netter (1983) Neuronal acquisition of tetanus toxin binding sites: Relationship with the last mitotic cycle. Dev. Biol. 100: 350-357.

Lasher, R. S. (1974) The uptake of $\left[{ }^{3} \mathrm{H}\right]-\mathrm{GABA}$ and differentiation of stellate neurons in cultures of dissociated postnatal rat cerebellum. Brain Res. 69: 235-254.

Leon, A., L. Facci, G. Toffano, S. Sonnino, and G. Tettamanti (1981) Activation of $\left(\mathrm{Na}^{+}, \mathrm{K}^{+}\right)$ATPase by nanomolar concentrations of GM1 ganglioside. J. Neurochem. 37: 350-357.

Leon, A., L. Facci, D. Benvegnù, and G. Toffano (1982) Morphological and biochemical cffects of gangliosides in neuroblastoma cells. Dev. Neurosci. 5: 108-114.

Leon, A., D. Benvegnù, R. Dal Toso, D. Presti, L. Facci, O. Giorgi, and G. Toffano (1984) Dorsal root ganglia and nerve growth factor: A model for understanding the mechanism of GM1 effects on neuronal repair. J. Neurosci. Res. 12: 277-287.

Matta, S. G., G. Yorke, and F. J. Roisen (1986) Neuritogenic and metabolic effects of individual gangliosides and their interaction with nerve growth factor in cultures of neuroblastoma and pheochromocytoma. Dev. Brain Res. 27: 243-252.

Montecucco, C. (1986) How do tetanus and botulinum toxins bind to neuronal membranes? Trends Biochem. Sci. 11: 314-317.

Morgan, J. I., and W. Seifert (1979) Growth factors and gangliosides: A possible new perspective in neuronal growth control. J. Supramol. Struct. 10: 111-124.

Moss, J., P. H. Fishman, V. C. Manganiello, M. Vaughan, and R. O. Brady (1976) Functional incorporation of gangliosides into intact cells: Induction of choleragen responsiveness. Proc. Natl. Acad. Sci. USA 73: 1034-1037.

Obata, K., M. Oide, and S. Handa (1977) Effects of glycolipids on in vitro development of neuromuscular junction. Nature 266:369-371.

Oderfeld-Nowak, B., M. Skup, J. Ulas, M. Jezierska, M. Gradkowska, and M. Zaremba (1984) Effect of GMl ganglioside treatment on postlesion responses of cholinergic enzymes in rat hippocampus after various partial deafferentiations. J. Neurosci. Res. 12: 409-420.

Partington, C. R., and J. W. Daly (1979) Effect of gangliosides on adenylate cyclase activity in rat cerebral cortical membranes. Mol. Pharmacol. 15: 484-491.

Prochiantz, A., U. Di Porzio, A. Kato, B. Berger, and J. Glowinski (1979) In vitro maturation of mesencephalic dopaminergic neurons from mouse embryos is enhanced in presence of their striatal target cells. Proc. Natl. Acad. Sci. USA 76: 5387-5391.

Prochiantz, A., M. C. Daguet, A. Herbert, and J. Glowinski (1981) Specific stimulation of in vitro maturation of mesencephalic dopaminergic neurons by striatal membranes. Nature 293: 570-572.

Radsak, K., G. Schwarzmann, and H. Wiegandt (1982) Studies on the cell association of exogenously added sialoglycolipids. Hoppe Seyler's Z. Physiol. Chem. 363: 263-272.

Robb, G. A., and R. J. Keynes (1984) Stimulation of nodal and terminal sprouting of mouse motor nerves by gangliosides. Brain Res. 295: 368-371.

Roisen, F. J., H. Bartfeld, R. Nagele, and G. Yorke (1981) Ganglioside stimulation of axonal sprouting in vitro. Science 214: 577-578.

Rybak, S., I. Ginzburg, and E. Yavin (1983) Gangliosides stimulate neurite outgrowth and induce tubulin mRNA accumulation in neural cells. Biochem. Biophys. Res. Commun. 116: 974-980.

Sabel, B. A., M. D. Slavin, and D. G. Stein (1984) GM1 ganglioside treatment facilitates behavioral recovery from bilateral brain damage. Science 225: 340-342.

Sabel, B. A., G. L. Dunbar, W. M. Butler, and D. G. Stein (1985) GM1 gangliosides stimulate neuronal reorganization and reduce rotational asymmetry after hemitransections of the nigro-striatal pathway. Exp. Brain Res. 60: 27-37.

Sbaschnig-Agler, M., R. W. Ledeen, B. Grafstein, and R. M. Alpert (1984) Ganglioside changes in the regenerating gold fish optic system: Comparison with glycoproteins and phospholipids. J. Neurosci. Res. 12: 221-232.

Schwartz, M., and N. Spirman (1982) Sprouting from chicken embryo dorsal root ganglia induced by nerve growth factor is specifically inhibited by affinity-purified antiganglioside antibodies. Proc. Natl. Acad. Sci. USA 79: 6080-6083.

Schwarzmann, G., P. Hoffmann-Bleihauer, J. Schubert, K. Sandhoff, and D. Marsh (1983) Incorporation of ganglioside analogues into fibroblast cell membranes. A spin-label study. Biochemistry 22: 50415048.

Skaper, S. D., and S. Varon (1985) Ganglioside GM1 overcomes serum inhibition of neuritic outgrowth. Int. J. Dev. Neurosci. 3: 187-198.

Skaper, S. D., R. Katoh-Semba, and S. Varon (1985) GM1 ganglioside accelerates neurite outgrowth from primary peripheral and central neurons under selective culture conditions. Dev. Brain Res. 23:19_ 26.

Skaper, S. D., R. Katoh-Semba, L. Facci, and S. Varon (1986) Ganglioside effects on astroglial cells in vitro. In Gangliosides and Neuronal Plasticity, G. Tettamanti, R. W. Ledeen, K. Sandhoff, Y. Nagai, and G. Toffano, eds., pp. 271-282, Liviana, Padova.

Sofroniew, M. V., R. C. A. Pearson, A. C. Cuello, P. C. Tagari, and P. H. Stephens (1986) Parenterally administered GM1 ganglioside prevents retrograde degeneration of cholinergic cells of the rat basal forebrain. Brain Res. 398: 393-396.

Sonderfeld, S., E. Conzelmann, G. Schwarzmann, J. Burg, U. Hinrichs, and K. Sandhoff (1985) Incorporation and metabolism of ganglioside GM2 in skin fibroblasts from normal and GM2 gangliosidosis subjects. Eur. J. Biochem. 149: 247-255.

Sonnino, G., R. Ghidoni, G. Galli, and G. Tettamanti (1978) On the structure of a new, fucose containing ganglioside from pig cerebellum. J. Neurochem. 31: 947-956.

Sparrow, J. R., and B. Grafstein (1982) Sciatic nerve regeneration in ganglioside-treated rats. Exp. Neurol. 77:230-235.

Sparrow, J. R., C. McGuinness, M. Schwartz, and B. Grafstein (1984) Antibodies to gangliosides inhibit goldfish optic nerve regeneration in vivo. J. Neurosci. Res. 12: 233-243.

Spiegel, S., P. H. Fishman, and R. J. Weber (1985) Direct evidence that endogenous GM1 ganglioside can mediate thymocyte proliferation. Science 230: 1285-1287.

Spoerri, P. E. (1983) Effects of gangliosides on the in vitro development of neuroblastoma cells: An ultrastructural study. Int. J. Dev. Neurosci. 6: 383-391.

Svennerholm, L. (1963) Chromatographic separation of human brain gangliosides. I. Neurochem. 10: 613-623.

Tettamanti, G., F. Bonali, S. Marchesini, and V. Zambotti (1973) A new procedure for the extraction, purification and fractionation of brain gangliosides. Biochim. Biophys. Acta 296:160-170.

Tettamanti, G., S. Sonnino, R. Ghidoni, M. Masserini, and B. Venerando (1985) Chemical and functional propertries of gangliosides. Their possible implication in the membrane-mediated transfer of information. In Physics of Amphiphiles: Micelles, Vesicles and Microemulsions, V. de Giorgio and M. Corti, eds., pp. 607-636, XC Corso Soc. Italiana di Fisica, Bologna.

Thompson, L. K., P. M. Horowitz, K. L. Bentley, D. D. Thomas, J. F. Alderete, and R. J. Klebe (1986) Localization of the gangliosidebinding site of fibronectin. J. Biol. Chem. 261: 5209-5214.

Toffano, G., G. Savoini, F. Moroni, G. Lombardi, L. Calzà, and L. F. Agnati (1983) GM1 ganglioside stimulates the regeneration of dopaminergic neurons in the central nervous system. Brain Res. 261: 163-166.

Toffano, G., G. Savoini, F. Moroni, G. Lombardi, L. Calzà, and L. F. Agnati (1984) Chronic GM1 ganglioside treatment reduces dopamine cell body degeneration in the substantia nigra after unilateral hemitransection in rat. Brain Res. 296: 233-239.

I suji, S., M. Arita, and Y. Nagai (1983) GQlb, a bioactive ganglioside that exhibits novel nerve growth factor (NGF)-like activities in two neuroblastoma cell lines. J. Biochem. 94: 303-306.

Vyskocil, F., F. Di Gregorio, and A. Gorio (1985) The facilitating effect of gangliosides on the electrogenic $\left(\mathrm{Na}^{+} / \mathrm{K}^{+}\right)$pump and on the resistance of the membrane potential to hypoxia in neuromuscular preparation. Pfluegers Arch. 403: 1-6.

Williams, L. R., S. Varon, G. M. Peterson, K. Victorin, W. Fischer, A. Björklund, and F. H. Gage (1986) Continuous infusion of nerve growth factor prevents basal forebrain neuronal death after fimbria fornix transection. Proc. Natl. Acad. Sci. USA 83: 9231-9235.

Willinger, M., and M. Schachner (1980) GM1 ganglioside as a marker for neuronal differentiation in mouse cerebellum. Dev. Biol. 74: 101117.

Wojcik, M., J. Ulas, and B. Oderfeld-Nowak (1982) The stimulating effect of ganglioside injections on the recovery of choline acetyltransferase and acetylcholinesterase activities in the hippocampus of the rat after septal lesions. Neuroscience 7:495-499. 